\title{
Working with Documentaries in the EFL Classroom: Successful Strategies for Decreasing Anxiety during Oral Tests
}

\author{
Jenaro A. Díaz-Ducca \\ Universidad Estatal a Distancia \\ Costa Rica
}

\begin{abstract}
This article describes the implementation and results of an action research project where documentaries were used as input in order to decrease student selfperceived anxiety during oral assessment activities (round tables.) This action research project was developed in an open English program for adults in a public university in Costa Rica. Among the main results, 77\% of students reported final decreased levels of anxiety when speaking in public, as well as increased motivation and self-confidence. The most successful strategies were choosing relevant topics, the use of English captions, previous discussion for clarifying content comprehension, teacher and peer scaffolding, and time for students to prepare their notes. Students also showed an interest in watching more materials and engaging in non-assessed oral discussions as ways to further cope with anxiety.
\end{abstract}

Key words: videos in the classroom, documentaries in the classroom, anxiety, oral assessment, round tables, oral production strategies, action research

\begin{abstract}
Resumen
Este artículo describe la implementación y los resultados de un proyecto de investigación acción donde se utilizaron documentales como insumo para disminuir los niveles de ansiedad autopercibida por los estudiantes, durante evaluaciones orales (mesas redondas). El proyecto se desarrolló en un programa libre de inglés para adultos en una universidad pública de Costa Rica. Entre los resultados, 77\% de los estudiantes reportaron menores niveles finales de ansiedad al hablar en público, así como mayor motivación y autoconfianza. Las estrategias más exitosas fueron: escoger temas relevantes, uso de subtítulos en inglés, discusiones previas para aclarar el contenido y la comprensión, apoyo (scaffolding) tanto del profesor como de los pares, y tiempo para preparar las notas de sus intervenciones. Los estudiantes también mostraron un interés en ver más materiales y participar en discusiones no evaluadas como medios para seguir lidiando con la ansiedad.
\end{abstract}

Palabras claves: videos en el aula de inglés, documentales en el aula de inglés, ansiedad, evaluación oral, mesas redondas, estrategias para la producción oral, investigación acción 


\section{The Problem}

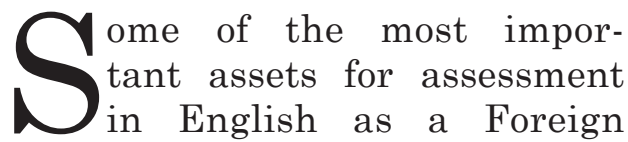
Language (EFL) are oral tests. Oral tests are used to evaluate students' performance as well as the degree of accuracy when using target grammar, vocabulary, and pronunciation. In the words of O'Malley (1996), "assessment of oral language should focus on a student's ability to interpret and convey meaning for authentic purposes in interactive contexts" (p.61). In general, however, oral tests tend to rise student anxiety no matter how authentic or interactive such contexts might be. In the particular case of the EFL class, anxiety and nervousness become disruptive elements that play against the students' abilities and actual level of proficiency. In other words, oral evaluation frequently implies student anxiety and all its manifestations. This is an element that instructors should keep in mind at all times so as not to misjudge student abilities. However, what can teachers do about student anxiety during oral tests?

From the students' perspective, then, dealing with oral assessment and anxiety represents a crucial set of skills and abilities they should develop during their learning process. In fact, coping with anxiety in a Second Language (L2) becomes more and more important since a considerable percentage of adult EFL students will use target language in the professional or academic fields, where supervision and assessment are always present.

In order to explore new possibilities on how to reduce student anxiety, this research was designed with the idea of incorporating documentaries and assist students during the preparation stages of oral assessments, in this case, round table discussions.

\section{Importance of Researching this Problem}

Although learners receive hundreds of hours devoted to grammar, vocabulary, and pronunciation, development of skills for speaking in public or making presentations in front of the class is in many cases neglected. Acquiring, enhancing, and continually applying these abilities is a must in a globalized world where working under pressure, helping customers, solving problems in the office, defending ideas in meetings, presenting a topic to an audience, or persuading potential buyers are daily tasks. In addition, EFL users are expected to be proactive, that is, to be able to anticipate difficulties, take the initiative, and provide feedback and self-criticism. In all of these scenarios, speaking in front of others and under scrutiny originates nervousness and anxiety, affecting performance and the goals.

Besides, training and experience have proven to teachers that the EFL classroom can be used as a laboratory for learning, applying, and improving linguistic contents as well as acquisition of production skills. In this sense, learning to face anxiety ought to be part of the EFL curriculum. Nevertheless, due to different reasons like curricular or time limitations, addressing these skills in class may be left to the instructor's own interest or the students' overt request.

On the other hand, technology and Internet are changing the way classes 
are taught and also the ways students learn. Teachers have now the role of coach and facilitator (Shelly, 2007a). As Quesada (2006) mentions, "Current generation teachers serve to assist students in organizing learning activities where students construct understandings around authentic and meaningful collaborative experience" (p.7). As part of this collaborative experience, video can offer rich input in terms of ideas, vocabulary, and pronunciation. Furthermore, films and documentaries present target topics and linguistic content to students in an attractive way that meets their needs and interests allowing them to focus on the ideas, diverting their attention from language itself (Katchen, 2003). This focus on content, rather than on language, as this research confirmed, effectively reduced students' perceived anxiety during oral tests.

\section{Focus of the problem}

Conducive to summarizing the points introduced above, this paper will focus in first place on the use of documentaries in the classroom as input during the pre-task stage for oral assessment. Video provided authentic content and ideas to be discussed and analyzed by students, and also useful vocabulary and target grammar structures to be evaluated as part of the course curriculum. The corresponding strategies to working with documentaries will be introduced in the Literature Review below and in the description of the action plan as it was implemented. In second place, the nature of classroom anxiety and its characteristics will be considered. It is important to remind the reader that oral assessment activities took the form of group work as round tables, which according to O'Malley's Oral Assessment Matrix (1996), included the language functions of describing, explaining, giving and asking for information, and agreeing and disagreeing. Finally, results of students' perceived anxiety will be presented, based on qualitative questionnaires and established by student self-evaluation.

Thus, the problem was formulated as: Can video be used to lower student anxiety prior to oral tests? With the intention of answering the question, this paper's hypothesis postulated that the use of videos as content input during the preparatory stages of round table discussions would act as an effective instrument to reduce student anxiety during the oral tests themselves. This assumption, as it will be seen below, was confirmed and in fact opened new perspectives on the usage of films and video in the classroom, the importance of preparing students for evaluated oral tasks, and the beneficial effects of low anxiety as a booster of students' self-confidence.

\section{Literature review}

\section{Using documentaries in the class- room: bringing life into the EFL class}

One of the most frequent complaints among teachers and students in the EFL context is the use of academic materials which, depending on the publisher and date of publication, may be out-of-date textbooks and recordings, have a "bookish" and artificial content, or could be full of dialectical variants (such as vocabulary and accent) and 
obsolete structures and words. Therefore, the English taught in class may not only be unrealistic and outdated, but might also be deeply unrelated to the students' needs in terms of contents and pronunciation. Moreover, motivation can decrease dramatically when traditional materials such as textbooks and academic recordings (in opposition to realia) are used in an exclusive and intensive manner in the EFL classroom.

On the other hand, the uses of video could add the "spice" needed to make classes motivating. As King (2002) points out,

Learning English by use of films compensates for all the shortcomings in the EFL learning experience by bringing language to life. It is a refreshing learning experience for students who need to take a break from rote learning of endless English vocabulary and drill practices, and replace it with something realistic, a dimension that is missing in textbook-oriented teaching. Films are such valuable and rich resources for teaching for they present colloquial English in real life contexts rather than artificial situations; an opportunity of being exposed to different native speaker voices, slang, reduced speeches, stress, accents, and dialects. (In Uner, 2009, p.1).

\subsection{Advantages to the Use of Videos in the EFL Classroom}

In this way, in addition to the advantages in terms of relevance and topicality, that is, the correspondence to the students' true linguistic and extralinguistic needs (academic, professional, cultural), the most important benefit to the use of videos is that of increasing student motivation in the classroom.
This benefit extends also to instructors: "One advantage of video use that has been shown is in the area of motivation (Chiang, 1996; Lin, 2002); students tend to find video material more interesting and are more likely to become involved in the lesson”. (in Katchen, 2003, p.3)

\subsection{Some initial considerations}

As an online publication by Alberta Learning points out (2003), video should be carefully selected. The instructor's criteria for that effect must be clear beforehand and should not respond to a simple whim or the "spur of the moment." The paper suggests that,

In choosing films for classroom study, teachers, schools and/or school jurisdictions need to consider how well the film will help students meet the outcomes, but they must also consider the quality of the film, appeal and appropriateness for students,community standards, copyright concerns, cost and availability. (p.1)

Thus, beyond the merits of a documentary in cinematographic or scientific terms, it must be pondered if the video will be attractive, easily available, and based on the students' needs and sensitivity, in addition to the school's and the community's. In the case of documentaries, furthermore, topics may be chosen by the students themselves, or can be based on the course curriculum.

\subsection{Strategies for using documenta- ries in the classroom as input for oral activities}

Reviewing the advantages mentioned above, once a video has been 
chosen, it is not simply a matter of coming into the class, setting up the equipment, and telling the students to try to understand as much as they can from the material. In fact, videos should be incorporated into the class and curriculum in order to secure a pedagogical and linguistic goal. Therefore, strategies to make the most out of a film as speaking input are very necessary. In the case of intermediate students, there are two main points to be kept in mind when teaching speaking, according to Bailey (2005).

Firstly, instructors need to "provide learners something to talk about" (p.36). If a movie is used as input, in a context where they have prepared in advance (for example, in the Pre-Task stage in Task-Based Instruction as a brief warm-up pair or group discussion, or linking this stage to a previous class or material.) This activity, as it has been established, will activate the students' relevant knowledge (schemata) and will also prepare them in terms of ideas, vocabulary, grammar, and pronunciation. Here, any assistance or scaffolding provided by the teacher will become very useful for the task ahead either in the form of handouts or using the board in a word splash, for example. Besides, questions for discussion can be suggested by the instructor, and a brief clarification discussion can take place before the actual round table (oral assessment activity.)

Secondly, instructors should "create opportunities for students to interact by using groupwork or pairwork" (p.38). In this way, when a film is used as a resource for theme content, the students will focus on the video itself and forget that they are in the English class. This can be achieved both in
Task-Based Instruction and ContentBased Instruction. By the time students start to watch the documentary, they will be effectively prepared in cognitive and linguistic terms. Then, once the video is over, they will be able to work on the task set by the instructor: writing a composition, talking to their partners, answering a questionnaire, or in the case discussed in this paper, engaging in a round table discussion where they should exchange their opinions based on aspects indicated by the instructor.

Lastly, the relevance of anxiety as the main obstacle for oral participation in class will be briefly addressed, especially when assessment and student production take place in the context of an oral activity in groups. This is a customary evaluation activity used in many adult EFL courses.

\section{Anxiety in the Classroom: some characteristics}

Most of people have experienced anxiety in the classroom at some point of their lives, be it in primary, secondary school, or at the university. Widely studied, anxiety can be considered a decisive factor in academic success: "Language anxiety consistently was among the strongest predictors of second language achievement" (Gardner et al. 1976, in MacIntyre et al., 2007, p. 278). In the English classroom, students commonly report feeling "butterflies in the stomach" when speaking in public or during an oral test. Horwitz et al in Lafont (2007) indicate that the researchers found anxiety develops mainly when oral participation is needed: "performance anxieties are communication apprehension, test 
anxiety, and fear of negative evaluation by their peers." (pp.30-31).

Furthermore, in addition to being very frequent in the language classroom, anxiety has been considered one of the most detrimental elements for student oral performance. "[It ] is the affective factor that most pervasively obstructs the learning process. It is associated with negative feelings such as uneasiness, frustration, self-doubt, apprehension, and tension. " (Heron, 1989 in Lafont, 2007, p. 29) For an extensive review on affective factors in the classroom, see Lafont (2007), and Díaz-Ducca (2013; 2014).

\subsection{Signs and manifestations of anxiety in the classroom}

As it has empirically been confirmed by most teachers, anxiety is commonly seen during oral activities and oral tests in particular. In the L2 classroom, however, anxiety takes place when using target language structures, vocabulary, and pronunciation, when students have to speak in public, or when they undergo evaluation by their instructors. Some of the observable signs of anxiety can be mentioned with the purpose of helping the teacher detect anxious students easily. Thus, Oxford (1990, in Lafont 2007) lists among others, "physical actions like squirming, fidgeting, playing with hair or clothing, nervously touching objects, stuttering or stammering... lack of eye contact ... exaggerated smiling, laughing, nodding, joking, excessive competitiveness..." (p.20)

On the other hand, language anxiety affects general performance and therefore fluency, accuracy, content (coherence), and class participa- tion (See Díaz-Ducca, 2013). Samimy and Tabuse, (1992) found out that "students who felt class discomfort (a lesser form of anxiety) were less likely to participate in risk-taking activities which may promote successful learning." (p.377) This is a reality that cannot be changed. However, for this action research, it was accepted that anxiety should be understood in its causes first, and then, neutralized as far as possible by the pre-speaking preparation students received before taking the actual test.

In order to record the incidence and signs of student anxiety in the classoom, five manifestations of anxiety, as categorized by Bailey (1995) and quoted by Hedge (2000) plus one described by MacIntyre (2007) and Gardner (1991), and one by the researcher (marked with *) were considered in the data collection instruments and analysis. These factors are shown in Figure 1.

Besides these manifestations, it is worth to briefly mention personality factors: extraverted vs. introverted; intuitive-random vs. sensing-sequential; thinking vs. feeling; and closure-oriented/judging vs. open/perceiving. (Oxford, 2003, p. 4) For the purposes of this study, these factors will only be included among the causes of students' perceived anxiety as "Personality" in opposition to "Previous experiences in the L2 classroom (see Instrument S1 below).

\section{Intervention Plan}

\section{Purpose of Research}

The purpose of this study was to establish the effects of using documentaries as input on the students' perceived 
Table 1

Manifestations of Anxiety in the Classroom (Bailey, 1995)

\begin{tabular}{|c|c|}
\hline Type of manifestation & Example \\
\hline Comparing self with others & "They speak better/worse than I do." \\
\hline Desire to outdo classmates & $\begin{array}{l}\text { With arguments, number of interventions, } \\
\text { pronunciation, grammar, vocabulary }\end{array}$ \\
\hline Worrying about the grade & "I want to get the best grade possible." \\
\hline Desire to get the teacher's approval & "Does the teacher agree with/like what I say?" \\
\hline $\begin{array}{l}\text { Desire to get classmates' approval * (Díaz- } \\
\text { Ducca) }\end{array}$ & “Do they agree with/believe/like me?" \\
\hline $\begin{array}{l}\text { Discrepancy between idealized image of } \\
\text { self as speaker and actual performance }\end{array}$ & "I could have done better than that." \\
\hline Previous traumatic experiences & Embarrassing situations in class \\
\hline
\end{tabular}

MacIntyre and Gardner, 1991)

anxiety during oral assessments, in the intermediate L2 classroom. Oral assessment activities were designed as round tables.

\section{Research Questions}

What strategies can be used with documentaries as input in order to help intermediate students focus on content during an assessed round table?

Can this focus on content lower student anxiety during an oral test?

Will students be aware of this change in their anxiety levels?

\section{Participants}

This research project was implemented during two 14-week terms, spanding for seven months, with four adult intermediate L2 groups in the context of an English language program offered by a public university in Costa Rica. The four groups encompassed the Common European Framework of Reference levels B1, B1+, B2, and B2+. Classes took place twice a week during the evenings (5-7 P.M., or 7-9 P.M.) or weekly on Saturdays (8-12 P.M.) for a total of four hours per week. Oral assessments were held three times during each term. Most learners were either college students or working professionals, a few housewives and two retirees, aging between 20 and 65 years old.

\section{Research Intervention}

Once the area of interest, variables, and literature review had been addressed, an intervention was designed. First, students were given a list of titles of documentaries, so they could choose three: one to be watched before each round table. In this case, documentaries dealing with dreams, longevity, and stress were the most voted for by students. During each session, students received warm-up questions to activate their prior knowledge and schemata (a sample of these questions will be found in the Appendices section). 
Then, as suggested by Katchen (2003), English captions were used while students watched the documentaries, to enhance their comprehension. Each student received a "Generating question", which by being answered, would give structure to their 3-minute intervention in each round table. Students were asked to provide examples from both the video and personal experience or other sources to support their arguments (a sample of the round table guidelines can be found at the end of this report.)

Before each assessed round table, nevertheless, a short informal discussion was carried out, with the purpose of answering student questions, reviewing vocabulary and pronunciation, and verifying comprehension of the documentary's main ideas as a point of departure. This allowed the teacher-researcher to monitor student mastery over content matter and interest before the assessment itself. In the case of biweekly courses, the video was watched and discussed in one session, while round tables were held in the next. For weekly courses, watching the video, discussing it, and participating in the round table all took place in the same session.

\section{Steps}

a. Students completed a survey prior to oral evaluations (S1).

b. Students choose three documentaries to be watched based on a list proposed by teacher.

c. Round tables were held at different dates during each course and teacher-researcher wrote down diary entries after each assessed activity.

d. Students completed a second survey after all three of the round tables (S2).

e. Teacher-researcher and students had an open discussion regarding the experience of working with documentaries and their perceived levels of anxiety.

\section{Timeline}

a. Students chose three documentaries: Week \#1

b. Students filled in First survey (S1): Week \#2

c. First Round Table held: Week \#6

d. Second Round Table held: Week \#9

e. Third Round Table held: Week \#12

f. Second survey (S2) filled: Week \#13

g. Open discussion with students' feedback: Week \#14

\section{Resources and Materials}

The intervention resources used were handouts which included warmup questions for each documentary, procedures for each round table, and "Generating Question" slips (see Appendices section). The teacher-researcher used a printed list with titles of documentaries to be chosen at the beginning of the course, a laptop computer for diary entries on the days of each round table and the final open discussion, and captioned versions of 60-minute documentaries such as those issued by the BBC and National Geographic Channel in avi format. These were played in either DVD players or laptop computers connected to flat-screen monitors as issued by the Language Program of the institution.

\section{Instruments used to assess stu- dents' anxiety during oral activities}

Qualitative instruments were designed incorporating theoretical elements 
discussed in the Literature Review, such as strategies for using movies in the classroom, and anxiety as experienced during oral tests. These instruments would assess the students' perceived anxiety both at the beginning and end of each course where the action research project was developed.

As data sources, students filled out one survey at the beginning of the course and one at the end, and the teacher-researcher wrote diary entries after each assessed session. In addition, an open discussion with each group took place during the final week of classes, in order to hear the general impression of students about the experience of using documentaries as content material for oral assessments, and their perception of the anxiety levels they felt during the tests.

\subsection{Description of first instrument to be used at the beginning of the cour- se (S1)}

The first qualitative questionnaire was designed with five questions, four close-ended and one open-ended. The objective of this instrument was to establish the original perceived level of anxiety of students, its causes and manifestations, and if their impression was that anxiety had changed throughout their previous learning process before enrolling in the current course. A copy of this questionnaire (in Spanish) can be found at the end of this article.

\subsection{Description of second instrument used near the end of the course (S2)}

In a similar way to the previous instrument, the second qualitative questionnaire was filled out by the students in order to determine their final perception of anxiety after the three oral quizzes planned in the course. It was designed with three close-ended and two open-ended questions.

\section{Analysis of results}

\subsection{Students' background: perceived initial levels and origins of anxiety}

In general terms, the first survey reported the status of students at the beginning of the course related to speaking in public and anxiety. Questions 1 and 2 shed light on their "anxiety background" as they perceived it, which was one of the main axes of this study. In Figure 2, a breakdown of their answers can be seen as corresponding to each Common European Framework level, and then as the average across the four groups. The main findings reflected that students tend to feel anxious when speaking in public (80.25\%); that anxiety is an adverse situation they feel has decreased with time (51\%) or remained costant $(42.75 \%)$; and that anxiety is originated in previous negative experiences in the classroom (58.5\%) and personalityrelated factors (41.5\%) as mentioned in the Literature Review above.

\subsection{Manifestations of anxiety: com- petitiveness, grades, and mistakes}

When asked to describe the manifestations of anxiety experienced (as detailed in Figure 1 in the Literature Review), students indicated that they compared themselves to others (competitiveness), worrying for their grade, and realizing that they made mistakes (a fear of making them or 
Table 2

Results of Survey 1 (S1)

\begin{tabular}{|c|c|c|c|c|c|}
\hline CEF Level * & B1 & B1+ & B2 & B2+ & Total:** \\
\hline $\begin{array}{l}\text { Number of students } \\
\text { in each group }\end{array}$ & 9 & 10 & 8 & 13 & 40 \\
\hline \multicolumn{6}{|c|}{ Students' answers: (in percentages \%) } \\
\hline $\begin{array}{l}\text { Question 1: } \\
\text { Do you feel anxious } \\
\text { when speaking in public? }\end{array}$ & $\begin{array}{l}\text { Yes: } 77 \\
\text { No: } 23\end{array}$ & $\begin{array}{l}\text { Yes: } 90 \\
\text { No: } 10\end{array}$ & $\begin{array}{c}\text { Yes: } 100 \\
\text { No: } 0\end{array}$ & $\begin{array}{l}\text { Yes: } 54 \\
\text { No: } 46\end{array}$ & $\begin{array}{l}\text { Yes: } 80.25 \\
\text { No: } 19.75\end{array}$ \\
\hline $\begin{array}{l}\text { Question 2: } \\
\text { As an L2 student, } \\
\text { your anxiety has } \\
\text { through time. }\end{array}$ & $\begin{array}{c}\text { Increased: } 0 \\
\text { Decreased: } \\
33 \\
\text { Not } \\
\text { changed: } 66\end{array}$ & $\begin{array}{c}\text { Increased: } \\
10 \\
\text { Decreased: } \\
50 \\
\text { Not } \\
\text { changed: } 40\end{array}$ & $\begin{array}{c}\text { Increased: } 0 \\
\text { Decreased: } \\
75 \\
\text { Not } \\
\text { changed: } 25\end{array}$ & $\begin{array}{c}\text { Increased: } \\
15 \\
\text { Decreased: } \\
46 \\
\text { Not } \\
\text { changed: } 39\end{array}$ & $\begin{array}{c}\text { Increased: } \\
6.25 \\
\text { Decreased: } \\
51 \\
\text { Not changed: } \\
42.75\end{array}$ \\
\hline $\begin{array}{l}\text { Question 3: } \\
\text { My anxiety is due to } \\
\text {.*** }\end{array}$ & $\begin{array}{c}\text { Prev. Exp: } \\
89 \\
\text { Personality: } \\
11\end{array}$ & $\begin{array}{l}\text { Prev. Exp: } \\
80 \\
\text { Personality: } \\
20\end{array}$ & $\begin{array}{l}\text { Prev. Exp: } \\
50 \\
\text { Personality: } \\
50\end{array}$ & $\begin{array}{l}\text { Prev. Exp: } \\
30 \\
\text { Personality: } \\
70\end{array}$ & $\begin{array}{l}\text { Prev. Exp: } \\
\text { 58.5 } \\
\text { Personality: } \\
41.5\end{array}$ \\
\hline
\end{tabular}

*Common European Framework ** Overall average *** Previous Experiences

self-recrimination after having done so). This is a very competitive aspect of assessment: a direct attention to grades and performance in quantitative terms. It also may evidence a sense of perfectionism or the idea that mistakes are rather problems than normal occurrences in the learning process. Students seemed to compete against themselves as well as against their peers. This implied a "double" competition: trying to outdo others and at the same time, living up to their own performance standards during oral activities.

\subsection{Perceived final levels of anxiety}

Final levels of anxiety showed very impressive results regarding the efficacy of the use of documentaries and the corresponding preparation as a means to cope with anxiety during oral activities.
In fact, the final levels of anxiety perceived in the second survey (Instrument S2) reported very clear data. In this manner, $77.1 \%$ of students considered they felt less anxious, whereas $13.5 \%$ felt that their level had not changed (among these were some of those "nonanxious" according to question 1 in Instrument $\mathrm{S} 1$ ); and $9.4 \%$ said they felt more anxious. When asked directly if they thought documentaries had been useful to deal with anxiety, $72.2 \%$ considered videos had helped, whereas $16.6 \%$ thought they hadn't helped, and $11.08 \%$ were not sure about it. The results of each CEF level and the average can be found in Figure 3 .

\subsection{Observable signs of anxiety}

As said earlier, the teacher-researcher took notes after each oral 
Table 3

Results of Survey 2 (S2)

\begin{tabular}{|c|c|c|c|c|c|}
\hline CEF Level * & B1 & $\mathrm{B} 1+$ & B2 & B2+ & Total:** \\
\hline $\begin{array}{l}\text { Number of stu- } \\
\text { dents in each group }\end{array}$ & 8 & 14 & 8 & 10 & 40 \\
\hline \multicolumn{6}{|c|}{ Answers to questions: (in percentages \%) } \\
\hline $\begin{array}{l}\text { Question 1: } \\
\text { At the end of the } \\
\text { course I feel } \\
\text { anxious. }\end{array}$ & $\begin{array}{c}\text { Less: } 75 \\
\text { More: } 12.5 \\
\text { Equally: } 12.5\end{array}$ & $\begin{array}{c}\text { Less: } 78.5 \\
\text { More: } 0 \\
\text { Equally: } \\
21.5\end{array}$ & $\begin{array}{c}\text { Less: } 75 \\
\text { More: } 25 \\
\text { Equally: } 0\end{array}$ & $\begin{array}{c}\text { Less: } 80 \\
\text { More: } 0 \\
\text { Equally: } \\
20\end{array}$ & $\begin{array}{c}\text { Less: } 77.1 \\
\text { More: } 9.4 \\
\text { Equally: } 13.5\end{array}$ \\
\hline $\begin{array}{l}\text { Question 2: } \\
\text { Did working with } \\
\text { documentaries } \\
\text { help you to deal } \\
\text { with anxiety? }\end{array}$ & $\begin{array}{l}\text { Helped: } 100 \\
\text { Didn't help: } 0 \\
\text { Not sure: } 0\end{array}$ & $\begin{array}{c}\text { Helped: } \\
64.3 \\
\text { Didn't } \\
\text { help: } 21.4 \\
\text { Not sure: } \\
14.3\end{array}$ & $\begin{array}{c}\text { Helped: } \\
75 \\
\text { Didn't } \\
\text { help: } 25 \\
\text { Not sure: } \\
0\end{array}$ & $\begin{array}{l}\text { Helped: } 50 \\
\text { Didn't } \\
\text { help: } 20 \\
\text { Not sure: } \\
30\end{array}$ & $\begin{array}{c}\text { Helped: } 72.32 \\
\text { Didn't help: } \\
16.6 \\
\text { Not sure: } \\
11.08\end{array}$ \\
\hline
\end{tabular}

* Common European Framework ** Overall average

evaluation in a diary in order to note down the observable signs of anxiety. Based on the physical signs of anxiety (Oxford in Lafont, 2003) evidenced during the round tables, the most important were fidgeting, occasional stammering, lack of eye-contact, exaggerated smiling, nodding, and some joking. Since assessments were round tables rather than debates, agreement or disagreement was not a relevant characteristic of the activities themselves. Excessive competitiveness, as listed among these physical signs in the Literature Review, was not evident in peer-to-peer interaction, perhaps due to the fact that antagonizing or persuading the others was not part of the task. This also confirms the students' own reports when asked about their aprehensions during the round tables regarding competing against their peers and against themselves (see Manifestations of anxiety above).

\subsection{Working with documentaries: most successful strategies}

Out of the strategies to be applied when working with videos in the class as detailed in the Literature Review, several were quoted by students when they answered Question 3 in Instrument S2 (see Appendices section). For example, students checked the most sucessful and useful for them: the topics were relevant and interesting, and watching the video with English captions. In this sense, their interests were met and that may have enhanced motivation (Chiang, 1996 in Katchen, 2003; Lin, 2002 in Katchen, 2003), in the first case, and captions actually contributed to comprehension (Katchen, 2003).

In addition, they also reported strategies like working with warm-up questions first; having a period for addressing questions and doubts prior 
to the round table; and taking time to prepare their notes. These pre-task activities such as warm-up questions allowed them to activate schemata, and previous discussions clarified content and language. During the note preparation stage, students had the chance of asking their peers, using the dictionary, looking for further information on internet, or resorting to the instructor if necessary. This scaffolding contributed to decreasing "stage fright" when the students' turn to speak came up during the round table. During the final course discussion, many learners referred to these "moments of preparation" as "more beneficial" than other activities. They claimed it had provided them with a time to "process" and "digest" information that they could later on express in "their own words."

\subsection{Students' recommendations: get- ting the most out of documentaries}

Part of the scope of this research was to receive feedback from students both with the $\mathrm{S} 2$ instrument and the final discussion which took place at the end of the course. Students were asked to offer recommendations on how to make the use of documentaries in particular and videos in general more productive in the classroom. They suggested that implementing "less-structured activities" such as open forums, and non-assessed activities like debates and games would allow them to talk more freely about the topics in the videos. In fact, they requested watching more videos about different subjects including ("more familiar" ones), holding discussions and presentations on a regular basis thoroughout future courses, and focusing specifically on the vocabulary and pronunciation necessary to effectively discuss each one.

\section{7 "Student, teach thyself": how to de- crease anxiety when speaking in public}

Another important source of information relevant to solving the problem of student anxiety was to draw from the learners' experience and interest in this matter in Question 5 of Instrument S2: How can you contribute to the decrease of your own anxiety? (see Appendices). Students offered different ideas: continuous practice (speaking in public); watching more documentaries; working on vocabulary; preparing enough for coming presentations; and learning speaking and self-relaxation strategies. As mentioned in the introduction to this report, oral production skills tend to be either neglected or not taught explicitly in many curricula due to the attention paid normally to course content and linguistic elements like grammar and vocabulary, or to the assessment itself. Once again, preparation and pre-task activities play a key role in the eyes of students, along with the actual application of these skills in oral practice and activities. This allusion to "preparation" was stressed by most learners during the final course discussion as an instrument to "forget about anxiety" as some of them put it.

\section{Conclusions}

While a decrease in anxiety cannot be equated to the disappearance of anxiety itself, the fact that students reported a clear improvement in their 
perception of anxiety opened new doors of possibilities for them and for the teacher. This implies wanting to participate more often, and as Samimy and Tabuse (1992) wrote, it could favorably predispose them for "risk-taking activities which may promote successful learning" (in Díaz-Ducca, 2013, p.71). As a matter of fact, teaching students how to deal with anxiety, and how to face a challenging task head-on, is a very valuable set of skills that can be applied in both their academic and professional lives.

To recapitulate, affective elements like motivation and self-confidence cannot be neglected if teachers intend to assist students defeat their language anxiety as far as possible. The use of videos in the classroom brings up students' self-confidence, and lowers their anxiety if a preparation stage is detailed enough. By providing scaffolding for vocabulary and pronunciation, as well as having an informal discussion prior to the round table, students increase their comprehension of the content material, organize their ideas, ask and answer questions, and work with tools like the dictionary or online resources. In this manner, by the time they have to speak in public, they are ready to perform given they feel they had enough preparation and coaching. In addition, the practice of group work as suggested by Bailey (2005) enriched both the pretask and task stages. Teacher and peer support and scaffolding had a remarkable influence in this process.

On the other hand, incorporating multiple intelligences as detailed by Gardner (1983) added diversity to the assessment activity cycle: visual, auditory, interpersonal, linguistic, musical, and intrapersonal intelligences were addressed during the pre-task and task stages. As Shelly et al (2007b) suggest, "most students are not only auditory or visual learners, but also multisensory learners. Digital media has the ability to capture the attention of the learner because it addresses a variety of learning styles." (p.23).

It should also be said that continuous inclusion of documentaries or movies, preparation stages, and engaging in non-assessed activities during one or two terms could dramatically potentiate students' self-confidence while lowering their performance anxiety. Following a detailed implementation plan may turn up interesting results and a marked improvement in many students. Some case studies can be developed so as to address specific cases of students suffering of high anxiety, or low self-confidence levels when speaking in public.

\section{Action Plan}

In the first place, one term may not be time enough to benefit all students affected by language anxiety. Although a minority, students who may still suffer from anxiety can be catered for during a longer academic period. Devoting more time to following up progress and development could offer more concrete data in terms of self-confidence for particular student populations. New challenges, implications, and possibilities of resorting to videos and coping with student anxiety could be discovered under such circumstances.

Likewise, developing case studies may also provide new insights into the anxiety-assessment binomial. Variables such as student personality and 
age should be explored further since almost half of the students expressed that anxiety arouse from their "personality". More information could allow for "customization" of both the materials to be watched and also for the steps and actual implementation of the oral assessments. As it was reported by the learners themselves, not only affective variables but also personality variables and traits influence student performance and grades.

Furthermore, action research allows for the extended monitoring of different linguistic processes in the classroom, in a dynamic and uninterrupted way. For example, as it was mentioned above, teaching and learning other skills such as speaking strategies, relaxation techniques, listening strategies, grammar acquisition, or pronunciation features such as intonation or particular phonemes could be studied too. Finally, other possible applications of videos in the EFL classroom as input include production activities like writing response texts, movie criticism, synopses, and more creative expressions like using cell phones so students can create their own short movies as creative multimedia tasks, reports, or final projects. All of these could be used for improving skills like vocabulary, grammar, or writing and speaking fluency, for example. Plenty of ideas for other creative activites and applications for videos and multimedia in the classroom can be found in Stempleski (1990), Shelly (2007b), and the Internet. Possibilities seem endless due to the multiple intelligences and skills addressed in movies and documentaries.

\section{Bibliography}

Alberta Learning (2003). Using Film in the Classroom, p.1. Retrieved from: http://education.alberta.ca/ media/883682/5_film.pdf

Bailey, K. M. (2005). Pactical English Language Teaching: Speaking. McGraw-Hill. pp.36-40, 96-97.

Chiang, H.-L. (1996). Students introducing their favorite English movies. Papers from the 12 th Conference on English Teaching and Learning in the Republic of China, 154-176. Taipei: The Crane Publishing Co., Ltd.

Díaz-Ducca, J. (2013). Effects of Affective Variables in L2 Fossilization in Adults: A Critical Literature Review. Innovaciones Educativas. 14:19. pp. 65-74.

Díaz-Ducca, J. (2014). Positive Oral Encouragement in the EFL Classroom, A Case Study through Action Research. Revista de Lenguas Modernas, 21. University of Costa Rica. pp. 325-346.

Duhaney, D. (2001). Teacher education: Preparing teachers to integrate technology. International Journal of Instructional Media, 28.1: pp. 23-24. Retrieved from: http://avmipapers.wikispaces.com/ file/view/Duhaney_Teacher+ed.Pre paring+teachers+to+integrate+tec hnology.pdf

Ehrman, M.E. (1996). Understanding second language learning difficulties. Sage Publications. p. 346.

Gardner, H. (1983). Frames of mind: The theory of multiple intelligences. New York: Basic Books.

Hedge, T. (2000). Teaching and Learning in the Language Classroom. Oxford University Press. pp. 20-21. 
Katchen, J.E. (2003). Teaching a Listening and Speaking Course with DVD Films: Can It Be Done? Retrieved from: http://mx.nthu. edu.tw/ katchen/professional/ festschrift.htm

Katchen, J.E. (2004). Analog to Digital: Technology Shift with Classroom Implications. p.7. Retrieved from: http://mx.nthu.edu.tw/ katchen/ professional/Singapore\%20Ana$\log \% 20$ to\%20Digital.pdf

Lafont, L. (2007). Study of Factors that Affect Oral Participation in the Students of $6^{\text {th }}$ Grade at María Auxiliadora School in Sahagún, Córdoba. (Master's Degree Thesis Report. Fundación Universidad del Norte). pp.30-31, 197. Retrieved from: http://manglar.uninorte.edu.co/bitstream/10584/702/1/25872147.pdf

Lin, L. Y. (2002). The Efffects of Feature Films upon Learners' Motivation, Listening Comprehension Performance and Speaking Skills: The Larner Centered Approach. Taipei: Crane Publishing Co.

MacIntyre, P. D., Clement, R., \& Noels, K. A. (2007). Affective variables, attitude and personality in context. In D. Ayoun (Ed.), Handbook of French Applied Linguistics. Philadelphia, PA: John Benjamins. pp. $270-298$.

MacIntyre, P. D. \& Gardner, H. (1991). Methods and Results in the Study of Anxiety and Language Learning: A Review of the Literature. Language Learning 41:1: pp.85-117. Retrieved from: http://faculty.cbu.ca/pmacintyre/ research_pages/journals/ methods_results1991.pdf

O'Malley, J.M., Valdez-Pierce, L. (1996). Authentic Assessment for
English Language Learners. Addison Wesley Publishing. p.61.

Oxford, R.L. (2003). Language Learning Strategies: An Overview. In GALA. pp. 3-7. Retrieved from: http://web.ntpu.edu.tw/ language/ workshop/read2.pdf

Quesada, A. (2006). Cyberl@b: A Platform for Learning English in Costa Rican High Schools. Actualidades Investigativas en Educación, 6.3. Retrieved from: http://revista.inie. ucr.ac.cr/uploads/tx_magazine/ cyberl@b.pdf

Samimy, K.K. \& Tabuse, M. (1992). Affective Variables and a Less Commonly Taught Language: A Study in Beginning Japanese Classes. Language Learning, 42.3. 377-398.

Shelly, G., Gammill, A. \& Irons, S. (2007). Integrating Technology into the Curriculum. Shell Education. pp.11-27.

Shelly, G., Cashman, T. \& Gunter, G. (2007). Teachers Discovering Computers: Integrating Technology and Digital Media in the Classroom. Shelly Cashman Series. pp.24-28.

Stempleski, S. \& Tomalin, B. (1990). Video in Action: Recipes for Using Video in Language Teaching. Prentice Hall.

Uner, H. (2009). Improving Speaking Skills by Using Films in the English Language Classroom: Bee Movie, a Film Workshop, p.1-9. Retrieved from: http://bildiri.anadolu. edu.tr/papers/bildirimakale/1625_ b864x68.pdf 


\section{APPENDIX}

\section{Appendix A}

\section{Handout 1: Warm-up Questions (PRE-VIDEO QUESTIONS)}

Instrucciones: Preguntas PRE: para todos (pre task) - 6' en tríos.

POST: Recortar las preguntas en tiras y que escojan para discutir. 10' antes de presentación.

"Why do we dream?": Discuss the following questions with your partners: - 6'

- Do you dream often?

- Do you remember your dreams?

- Do dreams have a meaning? Can they be interpreted?

- Tell your classmates about a dream you had recently

\section{Handout 2: Preguntas generadoras: Why do we dream?... (POST-VIDEO QUESTIONS)}

- What's the importance of REM sleep?

- What's the importance of scientific research on dreams?

- What's the relation of REM sleep and depression?

- Do dreams have a meaning? Can they be interpreted?

- Does our culture interpret dreams? Do you know any who do?

\section{Handout 3: Round Table about a movie/ documentary: (TASK)}

\section{* Instructions for Presenters:}

You need to talk for 3 minutes about a topic OR character OR scene OR quote from the movie. For documentaries, you may answer the "Pregunta generadora" given to you by the instructor. Offer examples from the video to support your point:

- Why did you choose it? What is your opinion?

- What extra information can you share? (examples from real life, anecdotes, quotes, etc.)

You MAY use sources like Wikipedia, IMDB, etc, BUT you need to present the information IN YOUR OWN WORDS and mention your sources. Use appropriate vocabulary and check pronunciation for key words in advance.

\section{* Instructions for Moderators:}

You need to introduce the topic by justifying its importance and relevance, direct the discussion by assigning turns to Presenters, write and ask ONE question to each Presenter, summarize the main points presented, and give your opinion at the end (Conclusions).

\section{* Steps For Our Round Table:}

I. Introduction (Moderator introduces topic and participants) - (3')

II. Presenters' participations - 3' each

III. Moderator asks questions to Presenters

IV. Presenters ask questions to each other (everybody should ask and answer at least one question)

v. Conclusions and Summary (Moderator) -5 


\section{Appendix B}

\section{... Cuestionario S1 sobre ansiedad al hablar en público ...}

Prof.JenaroA.Díaz-Ducca-www.jenarodiazducca.com

Instrucciones: Por favor conteste las preguntas de la manera más sincera posible. La información que nos dé es estrictamente confidencial y será utilizada para fines académicos exclusivamente. ¡Muchas gracias!

1. Antes de hablar en público, ya sea en grupos o individualmente,
a. me siento ansioso/a
b. no me siento ansioso/a

2. En mi experiencia como estudiante de inglés, esta ansiedad ha
a. aumentado con el tiempo
b. disminuido con el tiempo
c. permanecido igual

3. Mi ansiedad se debe a:

a. mis experiencias anteriores (hice el ridículo; otros se burlaron de mí; etc.)

b. mi propia personalidad (soy tímido, no me gusta hablar en público ni en castellano)

4. Mi ansiedad la puedo describir en estos términos (marque todas las opciones que se apliquen para Ud.)

a. Me comparo con otros ("otros hablan mejor/peor que yo")

b. Trato de superar a los demás (hablar mejor, mayor tiempo o más veces, "lucirme" con mi vocabulario, pronunciación, etc.)

c. Me preocupa mucho la nota que voy a obtener

d. Me preocupa que el profesor esté de acuerdo con lo que digo e. Me preocupa que mis compañeros estén de acuerdo con lo que digo

f. Me doy cuenta cuando termino de mis errores (algo que pronuncié mal o no pude decir)

g. Otra razón:

5. ¿Cómo cree Ud. que podría superar su ansiedad para hablar en público más tranquilamente?

\section{Appendix C}

\section{... Cuestionario S2 sobre ansiedad al hablar en público ...}

Prof. JenaroA. Díaz-Ducca-www.jenarodiazducca.com

Instrucciones: Por favor conteste las preguntas de la manera más sincera posible. La información que nos dé es estrictamente confidencial y será utilizada para fines académicos exclusivamente. ¡Muchas gracias!

1. Al finalizar el curso y después de haber hablado en público varias veces

a. me siento menos ansioso/a que antes

b. me siento más ansioso/a que antes

c. mi ansiedad no ha cambiado

2. Considera Ud. que trabajar con documentales

a. le ayudó a hablar con menor ansiedad

b. no le ayudó a hablar con menor ansiedad

c. no sabe si le ayudó

3. ¿Qué aspectos de trabajar con documentales antes de hablar en público le ayudaron a sentirse más seguro/a y así disminuir su ansiedad para hablar? (marque todas las opciones que se apli- 
quen para Ud.)

a. Los temas (interesantes y relevantes para mí)

b. Las preguntas de calentamiento antes de ver el documental

c. Las preguntas generadoras para escoger un tema del cual iba a hablar

d. Las discusiones que hicimos después del documental y antes de hablar en público

e. Ver el documental con subtítulos en inglés

f. Aclarar dudas con el profesor o los compañer@s durante las discusiones previas g. Preparar mis notas para saber qué iba a decir y con cuál vocabulario y gramática

h. Otro:

4. ¿De qué otras maneras ver documentales en el aula le puede permitir a los estudiantes hablar con menor ansiedad y más fluidamente?

5. ¿Cómo cree Ud. que puede contribuir para seguir disminuyendo su propia ansiedad de hablar en público en el futuro? 